\title{
Use of Cow as Draught Power in Some Selected Areas of Bangladesh
}

\author{
M.U. Rashid ${ }^{1 *}$, M. R. Rahman ${ }^{2}$ and Z. A. Mammun ${ }^{3}$ \\ ${ }^{1}$ Dept. of Agricultural Extension and Rural Development, Patuakhali Science and Technology University \\ Dumki, Patuakhali, Bangladesh \\ ${ }^{2}$ School of Agriculture and Rural Development, Bangladesh Open University, Bangladesh \\ ${ }^{3}$ Patuakhali Science and Technology University, Dumki, Patuakhali, Bangladesh \\ *Corresponding author and Email: murashidpstu@gmail.com
}

\begin{abstract}
The study was undertaken to investigate the use of cow as draught power in some selected areas of Bangladesh. Data were collected from 104 purposively sampled respondents from different parts of Tangail, Bogra, Rangamati, Narshindhi, Gopalgang, Gazipur, Chuadanga, Bhola, Faridpur and Barisal district by using interview schedule. It was found that 52 respondents $(50 \%)$ used both cow and machinery as source of farm power, while 23 respondents $(22.11 \%)$ used only animal and 29 respondents $(27.88 \%)$ used only machinery as the source of farm power. The study showed that top three purposes of using cow were cultivation, milking along with breeding and threshing. The farmers provided 24 suggestions to develop draught cow, among them the most common suggestions were increasing grazing land for draught animal, making animal feed available, launch training programmes for draught animal management and take preventive measures for controlling diseases of cow.
\end{abstract}

Keywords: Cow, draught power

\section{Introduction}

Livestock is a component of farming systems in Bangladesh which provides milk, meat and eggs for human consumption and raw materials for industries. Livestock sector contributes to $95 \%$ draught power in agriculture, $50 \%$ rural transportation, $10 \%$ organic fertilizer, $20 \%$ fuel, crushing and threshing of crops and sugarcane (BBS, 1994).

Technology has made tremendous strides in recent years providing fast, convenient and economic farm power and transportation. Extreme application of these innovations is admitted. However, it is still true that most of the power to do work on farms throughout the world is derived from humans and livestock. Contribution of working animal to agricultural production is enormously significant. This is especially so in rain fed agriculture in developing countries where motorized mechanization is out of the question for smallholder farmers. Working animals save human labour, and carry goods quickly. Crop residues and forages are recycled through manure, and soil fertility improves (Anonymous, 2003).

Bangladesh being an agrarian country, however her agriculture very has not been mechanized. The cattle and buffalo are the prime source of drought power contributing to 95 per cent of the requirement for preparation of land for cultivation and also for post harvest operations (Quddus, 1996).

In a developing country like Bangladesh, rapid mechanization of agriculture is restricted by of resources, scarcity of fuel, under developed 
communication and transportation system in rural areas. Besides, our land is also too fragmented which often limits the use heavy machineries. Our farmers are not financially solvent to buy agricultural machinery as well as they do not have enough training on using modern agricultural machinery. So, development of agriculture in a developing country like Bangladesh largely depends on development of draught animals. Therefore, the study was undertaken to:

1. To find out the extent of use of cow as draught animals.

2. To explore the present status of cow in different parts of Bangladesh.

3. To identify the ways through which our drought animals can be developed.

\section{Methodology}

The population of the study was the livestock farmers who have cows in some selected areas of Tangail, Bogra, Rangamati, Narshindhi, Gopalgonj, Chuadanga, Bhola, Faridpur, and Barisal. Purposive sampling method was employed to select 104 respondents. A structured interview schedule was used to collect primary information. The study was conducted during February to March, 2008.

\section{Results and Discussion}

\subsection{Selected characteristics of the respondents}

Data in Table 1 show the salient features of selected characteristics of the respondents. It was found that most of the respondents (49\%) belonged to medium farm size categories, while $43.3,3.9$ and $3.8 \%$ belonged to large, small and marginal farm size categories. About half $(46.6 \%)$ of the respondents had small number of cows and the rest 34.6 and $19.2 \%$ had medium to large number of animals, respectively. About equal proportion, 38.5 and $36.5 \%$ respondents supplied low to medium amount of feed to their animals and the rest $25 \%$ supplied high amount of feed to their cows. Most of the farms (42.3\%) had medium level production of milk, while the rest one third $(31.7 \%)$ had high production and $26 \%$ had low production of milk. In case of meat production, it was found that $41.4 \%$ farmers had medium production and the rest 28.8 and $29.8 \%$ had low and high production of meat, respectively.

\subsection{Use of cow as draught power}

Sources of power used for performing agricultural activities are shown in Fig.1. It is revealed that $22.11 \%$ of the respondent did their agricultural activities with animal power, while $27.88 \%$ performed their activities with machinery and the rest $50 \%$ of the respondents used both animal and machinery as their source of power for doing their agricultural activities.

Many people involved in farming on a small scale keep a variety of livestock and grow food and cash crops. When farming is carried out on a small-scale (on land areas of 1-4 ha), it is often not economic to use motor power for cultivation and cropping. Because of this many small-scale farmers make use of animal power to supplement manual labor for crop production and transport action (Simalenga et al., 2003).

\subsection{Use of cow in different purposes}

It was found that the responding farmers use cow mainly for cultivation purpose $(36.36 \%)$. The other activities for which animals are used were threshing (24.06\%), crushing (4.81\%), transportation (4.81\%) and others (29.94\%) (Table 2).

\subsection{Common diseases of cows}

A total of 28 types diseases of cow were identified, among which the most prevailing diseases according to rank order were worm, foot and mouth disease, diarrhoea, yoke gall, hump sore, dysentery, liver fluke disease, fever, milk fever and black quarter etc.(Table 3 ). 
Table 1. Descriptive statistics of some selected characteristics of the respondents.

\begin{tabular}{|c|c|c|c|c|c|c|c|c|}
\hline \multirow{2}{*}{$\begin{array}{c}\text { Selected } \\
\text { characteristics }\end{array}$} & \multirow{2}{*}{ Categories } & \multicolumn{2}{|c|}{ Respondent } & \multirow{2}{*}{$\begin{array}{l}\text { Scoring } \\
\text { method }\end{array}$} & \multicolumn{2}{|c|}{ Range } & \multirow{2}{*}{ Mean } & \multirow{2}{*}{$\mathrm{SD}$} \\
\hline & & No. & $\%$ & & Min & Max & & \\
\hline \multirow{4}{*}{$\begin{array}{l}\text { Family farm } \\
\text { size }\end{array}$} & Marginal(0.02- o.20 ha) & 4 & 3.8 & & & & & \\
\hline & Small farmer(0.21-1.0 ha) & 4 & 3.9 & Hectare & 0.08 & 14.71 & 1.92 & 2.52 \\
\hline & Medium farm(1.01-3.0 ha) & 51 & 49 & & & & & \\
\hline & Large farm(above 3.0 ha) & 45 & 43.3 & & & & & \\
\hline \multirow[t]{3}{*}{ Number of cow } & $\operatorname{Low}(1-3)$ & 48 & 46.2 & & & & & \\
\hline & Medium(4-6) & 36 & 34.6 & Number & 1.0 & 24 & 4.91 & 16.74 \\
\hline & $\operatorname{High}(7-24)$ & 20 & 19.2 & & & & & \\
\hline \multirow[t]{3}{*}{ Feed amount } & $\operatorname{Low}(2-6)$ & 40 & 38.5 & & & & & \\
\hline & Medium(6.1-9) & 38 & 36.5 & $\mathrm{Kg} /$ day/ye & 2.0 & 30.0 & 8.30 & 5.44 \\
\hline & $\operatorname{High}(9.1-30)$ & 26 & 25 & & & & & \\
\hline \multirow{3}{*}{$\begin{array}{l}\text { Milk } \\
\text { production }\end{array}$} & $\operatorname{Low}(0-2)$ & 27 & 26.0 & & & & & \\
\hline & Medium(2.01-12) & 44 & 42.3 & Liter/yr./f & 0.0 & 201.6 & 13.73 & 24.47 \\
\hline & $\operatorname{High}(12.01-202)$ & 33 & 31.7 & & & & & \\
\hline \multirow{3}{*}{$\begin{array}{l}\text { Meat } \\
\text { production }\end{array}$} & $\operatorname{Low}(0.01-1)$ & 30 & 28.8 & & & & & \\
\hline & Medium(1.01-5) & 43 & 41.4 & $\begin{array}{c}\mathrm{Kg} / \text { year/f } \\
\text { arm }\end{array}$ & 0.01 & 600 & 10.21 & 58.71 \\
\hline & $\operatorname{High}(5.01-600)$ & 31 & 29.8 & & & & & \\
\hline
\end{tabular}

Table 2. Use of cow in different purposes.

\begin{tabular}{lcc}
\hline Purposes & $\begin{array}{c}\text { Frequency ( no. of } \\
\text { respondents) }\end{array}$ & Percentage \\
\hline Cultivation & 68 & 36.36 \\
Threshing & 45 & 24.06 \\
Crushing & 9 & 4.81 \\
Transportation & 9 & 4.81 \\
Others(milking breeding) & 56 & 29.94 \\
\hline
\end{tabular}

Table 3. Common diseases of cow

\begin{tabular}{lcc}
\hline Name of disease & Frequency & Rank order \\
\hline Worm & 40 & 1 \\
Dysentery & 14 & 5 \\
Diarrhoea & 27 & 3 \\
Yoke gall & 17 & 4 \\
Hump sore & 13 & 6 \\
Foot and mouth disease & 39 & 2 \\
Black quarter & 9 & 10 \\
Liver fluke disease & 12 & 7 \\
Fever & 11 & 8 \\
Milk fever & 10 & 9 \\
\hline
\end{tabular}


Table 4. Suggestions proposed by the respondents for improving draught animal.

\begin{tabular}{lcc}
\hline \multicolumn{1}{c|}{ Suggestions } & Frequency & Rank \\
\hline Increasing grazing field & 23 & 1 \\
Availability of animal feed & 17 & 2 \\
Training on draught animal management & 15 & 3 \\
Decreasing feed price & 11 & 5 \\
Reducing price of medicine & 8 & 6 \\
Availability of vaccine and medicine & 8 & 6 \\
Take preventive measures for controlling animal diseases & 12 & 4 \\
Unavailability of veterinary doctor & 6 & 7 \\
Govt. should take special programme to develop draught animal & 6 & 7 \\
Lack of safe shelter & 6 & 7 \\
\hline
\end{tabular}

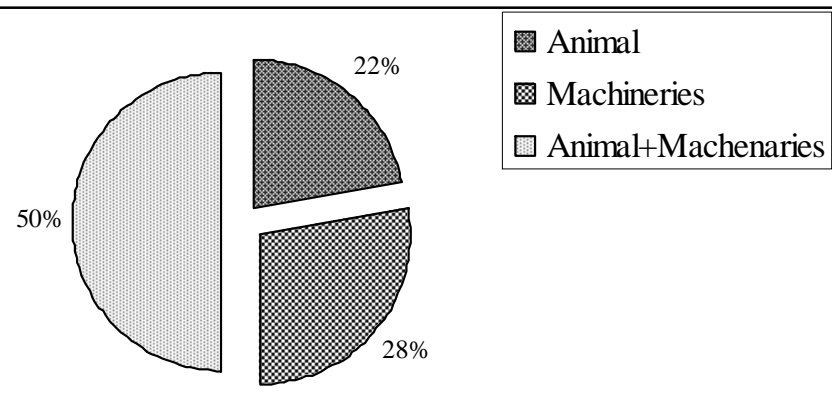

Fig. 1. Graph showing sources of power for different agricultural activities

\subsection{Suggestions for improving draught animal}

For improving draught animals the respondents proposed 24 suggestions. Among them the most common suggestions are given in rank order in Table 5.

It was observed that increasing grazing field, availability of animal feed and training on draught animal management were the three most important suggestions proposed by the respondents for improving draught animals.

\section{Conclusions}

Cows play an important role in supplying farm power. It had direct contribution to 22.12 per cent farm power, whereas it made other 50 per cent contribution to farm power combined with machinery. Cow is used for serving different purposes like cultivation, milking, breeding and threshing. Different problems including lack of grazing field, unavailability of animal feed, lack of training on managing draught animal, high price of animal feed and medicine, failure to develop potential draught breed etc. were observed in the context of managing and developing draught animals. Initiatives from governments as well as from private sector are required for overcoming the foresaid problems. 


\section{References}

Anonymous. 2003. Focus on Drought Animal Power. New Agriculturist on line. http://www.new-ag.info/03 4/focuson.html\#01

BBS. 1994. Statistical Yearbook of Bangladesh. 15th Edition. Bangladesh Bureau of Statistics. Ministry of Planning. Govt. Peoples Republic of Bangladesh. p.133.

Cole, H. H. and Ronning, M 1974. Animal Agriculture: The Biology of Domestic
Animal and Their Use by Man. W.H. Freeman Company, San Francisco.

Simalenga, T. E. and Pearson, R. A. 2003. Using Cow for Work. http://www.link.vet.ed.ac.uk/ctvm/Researc h/DAPR/Training\%20Publications/Cows $\% 20 \% 20001 / 9202$ Using_Cows.pdf

Quddus, M.A. 1996. Rural Development in Bangladesh: Strategies and Experience. Bangladesh Academy for Rural Development, Kotbari, Comilla. 